\title{
DIAGNOSTIC OPPORTUNITIES OF NEW TECHNIQUES OF MAGNETIC RESONANCE IMAGING IN DETECTING AND DIFFERENTIATING DEMENTIA SYNDROMES
}

\author{
MOŻLIWOŚCI DIAGNOSTYCZNE NOWYCH TECHNIK REZONANSU MAGNETYCZNEGO \\ W ROZPOZNAWANIU I RÓŻNICOWANIU ZESPOŁÓW OTĘPIENNYCH
}

Chair and Department of Radiology and Diagnostic Imaging, Collegium Medicum,

Nicolaus Copernicus University, Bydgoszcz

\begin{abstract}
S u m m a r y
Aging of population becomes an emerging health problem nowadays. One of symptoms of societal aging is an observed significant increase in the rate of dementia, which gradually excludes large group of patients from every aspect of life. Magnetic resonance imaging (MRI) is one of the most

techniques not only present structure and function of the brain, but also allow to assess metabolism, microcirculation and integrity if nervous tissue at the cellular level. The paper presents opportunities and perspectives of MRI in the diagnostics and differentiation of dementia.
\end{abstract} rapidly developing methods of neuroimaging. Modern MR

\section{Streszczenie}

Starzenie się populacji staje się coraz bardziej aktualnym problemem zdrowotnym naszych czasów. Jednym z przejawów starzenia się społeczeństwa jest obserwowany istotny wzrost częstości zespołów otępiennych i związane z tym stopniowe wyłączanie dużej grupy chorych $\mathrm{z}$ każdego aspektu życia. Badanie metodą rezonansu magnetycznego (MR) jest jedną $\mathrm{z}$ najszybciej rozwijających się metod obrazowania mózgu. Współczesne techniki MR stwarzają nie tylko możliwość oceny zmian strukturalnych i czynnościowych, ale również metabolizmu, mikrokrążenia i integralności tkanki nerwowej na poziomie komórkowym. Praca przedstawia możliwości i perspektywy badania MR w diagnostyce i różnicowaniu zespołów otępiennych.

Key words: magnetic resonance imaging, dementia, Alzheimer's disease

Stowa kluczowe: badanie metodą rezonansu magnetycznego, otępienie, choroba Alzheimera

\section{INTRODUCTION}

General improvement of living conditions and better health care systems resulted in a longer mean life span. Aging of the population is a significant social and medical problem of our times. It is estimated that in 1900, $1 \%$ of world population accounted for individuals over 65 years of age. In 1992 that percentage rate increased to $6.2 \%$ and according to prognoses, will reach as much as $20 \%$ in 2050 [1].

One of the symptoms of aging population is the witnessed significant increase in the incidence of dementia syndromes resulting in progressive exclusion of a large group of patients from every aspect of life. That is why the problem of advanced-age diseases is connected with increasing interest of researchers and also politicians (e.g. the document of the European Council from 2008, entitled Council Conclusions on public health strategies to combat neurodegenerative diseases associated with aging and in particular Alzheimer's disease). 
The main objectives of the research on degenerative syndromes of the elderly include searching for biomarkers, i.e. indicators or symptoms allowing early and reliable diagnosis of dementia. These may include aberrations in psychological tests, laboratory indicators or specific features of the brain that can be detected in imaging studies.

Searching for biomarkers of dementia focuses on such currently used imaging techniques as PET (positron emission tomography) and MRI (magnetic resonance imaging). The PET examinations, due to their limited accessibility, high price and exposition to ionizing radiation, seem to have less chance for a broad clinical use. Therefore, most examinations focus on the diagnostics of dementia with the use of MRI being a method that allows evaluation of brain morphology, chemical composition, ongoing metabolic processes and function. The aim of this work was to present possibilities and perspectives of the use of MRI in early diagnostics and differentiation of dementia syndromes.

\section{DEMENTIA SYNDROMES}

According to the definition of WHO, dementia syndrome is a set of symptoms caused by brain disease, usually a chronic or progressive one, clinically characterized by numerous disorders of higher cortical functions such as memory, thinking, orientation, reasoning, counting, ability to learn, language, and evaluation [1]. Moreover, disturbances of cognitive functions are frequently accompanied or even preceded by emotional, behavioral and motivational disorders. A more precise definition is given by DSM-IV (Diagnostic and Statistical Manual-American Psychiatric Association), which defines dementia as a set of symptoms of disturbed cognitive processes including, apart from disturbed memory, deficits of at least two functions from the following: speech (aphasia), voluntary complex movement (apraxia), ability to discriminate and identify objects (agnosis), as well as inability to plan, initiate, control and correct complex behaviors (disturbed executive functions) [2]. Moreover, cognitive deficits should be serious enough to disturb professional activity, social functioning and execution of everyday activities.

It seems that dementia is not a normal process of body aging. It can result from over 50 pathologies which cause primary or secondary disorders of the central nervous system (CNS). To systematize the background of the problem, we may distinguish 6 main etiological groups in the literature: vascular, degenerative, metabolic, infectious, toxic, and CNS injuries. The statistics and demographic data clearly show that the incidence rate of dementia is determined by age, i.e. the increasing rate of elderly individuals in the population is directly connected with increased incidence of dementia. Studies have shown that among individuals between 65 and 85 years of age the incidence is the highest and the main neurodegenerative disease is the Alzheimer's disease, and among individuals over 85 y.o.a., the vascular dementias are the most prevalent $[3,4]$.

The most numerous group includes vascular and degenerative dementias. The remaining conditions, although sporadic, require insightful differential diagnostics, as they are potentially reversible. In Europe, the dominant form of dementia is the Alzheimer's disease (AD), accounting for 50-60\% of all cases. It is followed by DLB dementia (dementia with Lewy bodies) and $\mathrm{VaD}$ (vascular dementias) $[3,4]$.

The Alzheimer's disease is a degenerative disease of the CNS, with progressive deficits of cognitive function and cortical disturbances - apraxia, aphasia, memory and behavior disorders, and psychotic symptoms. Early phase of AD reveals non-specific symptoms with dominant disturbances of memory. The disease is strictly age-determined. In individuals aged between 65 and 85 years, the incidence doubles every 5 years [4]. People with advanced AD are not able to function independently in their everyday life.

Dementia with Lewy bodies is characterized by cognitive disturbances with features of Parkinson's disease of changing type with delusions and hallucinations. Typical for this disease is hypersensitivity reaction and poor response to neuroleptics. The accompanying symptoms include syncope, repeated falls and transient disturbances of consciousness $[5,6]$.

Vascular dementia reveals a picture typical for subcortical disturbances: memory disturbances, changes of emotions and personality, executive function disturbances and slower information processing. Usually, these symptoms result from numerous minor strokes. Risk factors of $\mathrm{VaD}$ include mainly age, diabetes, atherosclerotic lesions of internal carotid, vertebral and cerebral arteries, hypercholesterolemia and stroke in past [7]. 
Diagnostics of dementia underscores 4 basic clinical features of the disease: the profile of cognitive disturbances, the onset and time sequences of appearing clinical symptoms, psychopathological disorders (psychotic syndromes and disturbed behaviour) and neurological symptoms [8]. These components are included in detailed criteria differentiating $\mathrm{VaD}$ from degenerative diseases of the brain. A thorough analysis of criteria of dementia supported by advanced MR imaging facilitates the proper diagnosis.

\section{DEMENTIA SYNDROMES IN IMAGING STUDIES - CURRENT IMAGING PRACTICES}

The main symptom of brain degenerative diseases includes disturbed cognitive functions. It is estimated that in half of the patients suffering from dementia, the disease was not diagnosed and according to NDS (National Dementia Strategy), dementia is diagnosed too late and too rare. Development of neuroimaging techniques facilitates clinical diagnosis of dementia, mainly by excluding the organic causes of brain disorders. Imaging methods used in the diagnostics of dementia may be divided into structural (CT, morphological MRI with volumetry, Doppler ultrasonography) and functional: evaluation of diffusion, diffusion tensor in MRI, evaluation of perfusion with MRI and CT, functional magnetic resonance (fMRI), as well as SPECT, i.e. single-photon emission computed tomography, and PET.

Owing to the availability of CT, this is frequently the first examination performed in a patient with dementia or suspected dementia. However, it should be remembered that its diagnostic capabilities are quite limited and the examination detects only some pathological lesions typical for dementia. In CT it is easy to evaluate brain atrophy (cortical, subcortical or mixed). Their location may suggest the type of dementia, e.g. AD-related atrophy of hippocampal area mostly, FTD-related atrophy of frontal and temporal lobes, subcortical atrophy in Hintington's disease and atrophy of frontal lobes and cerebellum in alcoholic dementia [9]. The evaluation of the degree of atrophy may be susceptible for subjective impreciseness of assessment, however linear measurements (Huckmann number, the width of the III ventricle, the width of lateral cerebral fissures) or evaluation of the volume of intracranial fluid spaces allow for fairly accurate tracking of neurodegenative changes over time. The degree of atrophy should be evaluated regarding the age of the patient. Moreover, an important advantage of atrophy evaluations is the possibility of a precise control of dementia changes in time [9].

Over the past years, morphological imaging of dementia with MRI has gained on importance. This tendency results from a higher contrast resolution of MRI as compared to CT, which enables precise evaluation of particular structures of the brain, e.g. hippocampus, typically undergoing atrophy in $\mathrm{AD}$, or the gray matter of the hemispheres selectively. Increased interest in dementia imaging with this method was a result of studies carried out by Award et al. [9, 10]. They showed that in MRI images of the studied patients, the incidence of lesions in the white matter reaches $22 \%$ in a group below 40 years of age, $51 \%$ among individuals aged 41-60, and 92\% among individuals over 60 y.o.a. To compare with, $\mathrm{CT}$ detects focal lesions in $7 \%$ of individuals aged $55-69$ years, and in less than $1 \%$ of individuals under the age of 45 [10]. The advantage of MRI over CT is also visible in the evaluation of ischemic lesions. This follows from a significantly higher sensitivity of T2-weighted images in detecting small ischemic lesions within basal ganglia, white matter, brain stem, and cerebellum. Specific MRI image allows also for diagnosing rare neurodengenerative diseases, such as HallevordenSpatz syndrome, Wilson or Creutzfeldt-Jakob disease [9].

\section{ADVANCED MRI TECHNIQUES IN DEMENTIA IMAGING}

\section{Morphometry}

VBM morphometry is a measurement of volume of the grey matter, comparing signal intensity within particular pixels of an image of a selected anatomical structure of the brain. The measurement of the volume of tissue structures or fluid spaces is carried out at sites strategic for a given type of dementia. On the basis of information thus received it is possible to evaluate the advancement of the disease as well as clinical prognosis of disease progression $[9,11]$.

However, it should be remembered that due to inter-individual variability of the size of the skull as well as insufficient specificity, the value of single linear measurements in the diagnostics of CT imaging may raise doubt. MRI imaging is characterized by high accuracy in volume evaluation - up to $0.1 \mathrm{~cm}^{3}$. Such a 
precision in measurements guarantees high repeatability and sensitivity of the method [10]. In case of high-resolution MRI imaging, software packages required for data processing generate planimetric and volumetric measurements. Planimetric measurements are obtained with area segmentation technique. This method uses the difference in signal intensity between the brain cortex, subcortical structures and the white matter [11]. Values obtained in such a way are normalized with regard to so called total intracranial volume [11]. The evaluation is made with the use of semi-automatic technique.

In order to obtain images, the IR (inversion recovery) sequences are used or typical T2-weighted images, in FSE (fast spin echo) sequence. Examinations with the use of VBM showed that in AD there is not only a typical atrophy of structures of the superior-medial part of the temboral lobes, but also atrophy within the insular cortex and caudate nuclei $[11,12]$.

Jack et al. [13] in their logitudinal studies showed that in the group of study patients with diagnosed AD and healthy, elderly individuals, a higher index of hippocampal atrophy was found in patients with $\mathrm{AD}$ (4-6\% a year). A similar interrelation was also shown for the entorhineal cortex [13]. This finding acknowledge volumetric measurements of the entorhineal cortex as dedicated indicator of clinical deterioration in patients with $\mathrm{AD}$ [14]. For evaluation of progression of brain atrophy, it is recommended to use a method which allows for "superimposition" of subsequent images and subtraction of the baseline image. As a result, the acquired image will include marked in color (usually red) areas of brain atrophy [11].

Magentic Resonance Spectroscopy (MRS) in the literature called ,window for tissue metabolism”. In MRS it is possible to non-invasively assess the amount of selected chemical compounds in tissues and indirectly draw conclusions on metabolism or cellular integrity of the examined area [15]. The spectroscopy uses signals of chemical compounds including nuclides not only $1 \mathrm{H}$ but also $13 \mathrm{C}, 19 \mathrm{~F}, 31 \mathrm{P}, 15 \mathrm{~N}$ and $23 \mathrm{Na}$. The result of the test is the resonance spectrum of the tested sample, shown in coordinates. The spectrum results from converting signals of free precession FID registered within a selected area.

The most frequently used method of localization is the SVS (single voxel sptectroscopy). It allows to ascribe a different resonance frequency to every examined area. Undoubtedly, the advantage of this method is high homogeneity of the study area, short examination time (4-8 $\mathrm{min}$ ), high signal-to-noise ratio and easiness in selective attenuation of water signal. Other localization methods include ISIS (Imageselected in vivo spectroscopy), PRESS (point-resolved localized spectroscopy) and STEAM (Stimulated echo acquisition mode). Differences between them involve changing RF impulse and coordinates of time sequences [10]. We should also mention the MultiVoxel technique. It allows for chemical shift imaging (CSI) and allows for simultaneous registration of signal from a few adjacent voxels. The acquired image is a map of selected metabolites with their spatial position in the examined layer of the organ $[10,16]$.

MRS has long been applied in studies on dementias [9]. Proton spectroscopy is the most frequently used one (hydrogen, 1HMRS). More rarely used, mainly due to equipment requirements, are phosphorus spectroscopy (31PMRS), fluorine spectroscopy (19FRS) and carbon spectroscopy (13CMRS). The 1HMRS allows for testing the following brain metabolites: NAA (N-acetylaspartate), choline and its metabolites, myoinositol, creatinine and creatinine phosphorane, as well as the glutamate-glutamine complex. NAA in immature oligodendrocytes is found mostly intracellularly. Thus, it is held for a marker of neuronal density and as an indicator of metabolic activity of nervous cells $[15,17]$ and NAA decrease is connected with neuronal atrophy [18]. In a normal spectroscopic image of the brain, it shows the highest peak.

MRS creates new possibilities of diagnostics of $\mathrm{AD}$ in living individuals. A typical picture of $\mathrm{AD}$ is as follows: lower NAA concentration, higher myoinositol concentration [9, 10]. Intensification of lesions is especially significant in associative centers. In a test differentiating healthy middle-aged individuals and patients with AD, MRS showed sensitivity of $83 \%$ and specificity of $98 \%$. In a test differentiating $\mathrm{AD}$ and other forms of dementia, MRS showed specificity of $64 \%$ and sensitivity of $82 \%$ [10].

In case of dementia with Lewy bodies, diagnostics with spectroscopy has been incidental so far. The reason was technical problems which can appear during the examination (parkinsonism, no cooperation of the patient and fluctuations of cognitive functions). So far, the first and the largest project aimed at spectroscopic examination in DLB was the study by 
Molina et al. [18]. It included 12 patients meeting the criteria for DLB. All included individuals had fluctuations of cognitive functions, visual hallucinations, and parkinsonism. The authors tried to evaluate brain metabolites in the temporal lobes and basal ganglia but the examination of the mentioned areas ended in failure due to no homogeneity of the brain in those areas. Significant differences in the concentration of metabolites between DLB and the control group were found only in the white matter.

Diffusion tensor imaging (DTI) is a technique of MRI used to visualize the course and to evaluate the integrity of the pathways of the white matter. DTI is an advanced diffusion technique which, apart from quantitative evaluation of free diffusion of water in the extracellular space of living tissues, expressed as MD (mean diffusivity) allows also for qualitative and quantitative evaluation of the direction of diffusion [17].

A natural barrier for free diffusion in the tissues of the cerebral and spinal white matter is the cell membrane and myelin sheath of axons. This is where the movement of water particles is limited and anisotropic - it is expressed by limited diffusion in perpendicular directions with regard to the white matter fibers. The degree of diffusion anisotropy is shown by FA (fractional anisotropy) parameter. FA is also called an index of white matter integrity [11]. A decrease in its value signals damage and degradation of white matter pathways or widening of the extracellular space in the course of vasogenic edema [19]. An additional option of DTI is tractography of diffusion tensor. This method visualizes in 3D the anisotropy of water diffusion in the white matter, which corresponds to the course of white matter fibers. Tractography uses an algorithm of drawing the course of continuity of fibers from a chosen point. It should be remembered that the registered course of fibers is averaged for every voxel [11].

DTI is widely used in the evaluation of dementia disorders [9]. In dementia there is a secondary degeneration of the fibers of the white matter, probably due to Waller degeneration, which concerns the associative pathways (longitudinal upper and lower bundles, fronto-occipital bundles, and posterior part of the cingulum), callosal pathways (ganu and splenium corporis callosi) [9]. Sąsiadek et al. showed the highest lowering of FA within the posterior cingulum, with a strong difference between $\mathrm{AD}$ and mild cognitive impairment (MCI), and between MCI and healthy population. DTI performed in the area of the posterior cingulum was the best in differentiating those groups of patients, showing superiority over MRS and PWI (perfusion weighted imaging), or even PET [9].

Functional MRI is a method presenting activation of the brain cortex in response to specific stimuli or at rest. The intensity of MRI signal is related to the degree of hemoglobin oxidation. Activation of neurons in response to a stimulus results in a decrease in oxyhemoglobin level in local microcirculation and increase of $\mathrm{CO} 2$ and deoxyhemoglobin level. As a result of autoregulation, the local blood flow rises after 2-6 sec, which causes an increase in the amount of oxyhemoglobin and washout of the deoxygenated form. Both forms of hemoglobin present different magnetic properties, which causes a change in MR signal intensity of $1-5 \%$ in the BOLD technique [20].

fMRI has a high linear and temporal resolution. It is carried out in two phases. The first one is the morphological (structural) examination. Next, the areas of the brain cortex are subjected to a series of active or passive (stimulus removal) stimulation separated by periods of rest [11]. After comparing images of activation obtained in control situation of rest and task, a map of brain activity is obtained, correlated with the influence of a selected component [21].

The fMRI examination in case of cognitive disorders gains on its importance. An essential role is played by the possibility of comprehensive evaluation of structural changes and brain function [11].

Scientific research with the use of fMRI are usually conducted on good-cooperating volunteers. The results of neuropsychological or movement tests are much better in those individuals than in patients. Patients with dementia have their cognitive functions tested. Therefore, when preparing the paradigms - tasks - it is necessary not only to include neuropsychologist's help but also to simplify stimuli adequately [11]. Cognitive testing of dementia is based on evaluation of working memory (remembering pictures, associating face with name), arithmetic functions (counting forward and backward, addition and subtraction), visual-spatial functions (comparing objects seen from different sides, identifying the angle between the arms of the clock) [10].

In $\mathrm{AD}$ there is a decreased activity of the cortex during performance of cognitive tasks, especially in parietal lobes and hippocampus [9]. It was also shown that specific changes in fMRI appear even before the occurrence of clinical features typical for $\mathrm{AD}$ : 
increased activity of the praecuneus and decreased activity within the middle part of temporal lobes and prefrontal cortex $[10,11]$. One should remember that the area of increased or decreased activity would point to disturbances of interaction between certain centers and not to their damage [11].

This method allows for an assessment of the influence of procognitive medications on memory functions during long-term therapy. Increased activity was found in the areas of the cortex stimulated during memorization [21]. fMRI may also be helpful in differentiating $\mathrm{AD}$ from other pathologies associated with dementia, e.g. the Parkinson's disease, vascular dementia or fronto-temporal dementia [22]. In case of $\mathrm{AD}$, it is extremely important to select patients at an early stage of the disease. $\mathrm{AD}$ is frequently preceded by the MCI. Distinguishing MCI patients with increased risk of development the $\mathrm{AD}$ is clinically challenging and fMRI seems to facilitate this.

Perfusion-weighted imaging (PWI) permits evaluation of brain microcirculation on the basis of changes in MR signal intensity. Depending on the technique applied, PWI allows for quantitative and qualitative evaluation (color maps, regional blood flow $(\mathrm{CBF})$, volume of blood in the vascular bed (CBV), and mean time of blood flow through microcirculation (MTT)). Examination of perfusion is used in detecting and differentiating the type of dementia and in monitoring of its progression.

PWI can be performed with or without administration of contrast media. Perfusion examination without the use of gadolinium preparations is carried out with the ASL (Arterial Spin Labelling) method, i.e. marking of blood spins. This technique includes saturation or inversion of arterial blood spins at the level of the neck, and then their detection in the measured volume. The marked spins, moving to the vascular bed of the brain, change magnetization of brain tissues, which is registered as dynamic change in signal intensity $[9,10,17]$. The second method requires i.v. injection of paramagnetic contrast agents and is based on the evaluation of a simple change in relaxation time $\mathrm{T} 1$ or uses the effect of magnetic susceptibility of the bolus, and it influences the relaxation time T2 (DSC). DSC is a more precise method but requires repeated acquisition of data during the first pass of the bolus, and thus poses high requirements for the equipment [10].

MR perfusion is valuable method in differentiating $\mathrm{VaD}$ and $\mathrm{AD}$ [11]. It can be also used in monitoring the progression of dementia. Walecki et al. showed that there is a correlation between $\mathrm{CBF}$ and $\mathrm{CBV}$ proportional to the MMSE score [14]. Decreased perfusion in cortex indicate dementia [9]. Location of abnormalities seen in PWI in different forms of dementia correlates well with SPECT results [9]. According to Sąsiadek et al., the most intensified perfusion abnormalities in dementia can be found within the cingulate and this may be the cue for differentiating AD patient from MCI patient, and MCI patient from a healthy person [9].

\section{REFERENCES}

1. Eight Report on the World Health Situation (1991) ; World Health Organization ; 89: 10

2. Wciórka J (2008) Kryteria diagnostyczne według DSMIV-TR. Wyd. Elsevier

3. Brockhuis B (2009) Zaburzenia perfuzji mózgowej oceniane metodą tomografii emisyjnej pojedyńczego fotonu (SPECT) u pacjentów $\mathrm{z}$ otępieniem $\mathrm{z}$ ciałmi Lewy'ego, chorobą Parkinsona oraz choroba Alzheimera. Rozprawa doktorska

4. Evans DA, Funkenstein HH, Albert MS, Scherr PA(1989) Prevalence of Alzheimer's disease in a community population of older person. Higher than previously reported. JAMA; 262: 2551-2556.

5. Dickson DW, Ruan D, Crystal H (1991) Hippocampal degeneration differentiates diffuse Lewy body disease (DLBD) from Alzheimer's disease: light and electron microscopic immunocytochemistry of CA2-3 neuritesspecyfic to DLBD. Neurology, 41: 1402-1409

6. McKeith IG, Galasko D, Kosaka K (1996) Consensus guidelines for the clinical and pathological diagnosis of dementia with Lewy bodies (DLB): report of the consortium on DLB international workshop. Neurology, 47: $1113-1124$

7. Ziółkowska-Kochan M (2003) Aspekty neurologiczne chorób otępiennych, Pomorski Magazyn Lekarski Miesięcznik Okręgowej Izby Lekarskiej w Gdańsku/ tom $125 \mathrm{nr} 1$.

8. Kwieciński H, Kamińska A.M (2008) Neurologia Merritta wyd. II polskie Tom 1.

9. Szczudlik A, Motyl R (2006) Standardy postepowania, Otępienie naczyniopochodne. Rozpoznawanie i leczenie otępień Rekomendacje Interdyscyplinarnej Grupy Ekspertów Rozpoznawania i Leczenia Otępień oprac. / red.

10. Roman G.C., Tatemichi T.K., Erkinjuntti T (1993)Vascular dementia: diagnostic criteria for research studies - Report of the NINDS-AIREN International Workshop. Neurology : 43: 250-260.

11. World Health Organization (1993): ICD-10 Classification of Mental and Behavioural Disorders: Diagnostic Criteria for Research. Genewa.

12. Sąsiadek M, Zimny A (2011) Współczesna diagnostyka obrazowa procesów otępiennych. Diagnostyka 
Neuroobrazowa w Stanach Otępiennych, Continuo, Wyd 2, 403-420.

13. Rombouts S.A, Barkhof F, Witter M.P (2000) Unbiased whole-brain analysis of gray matter loss in Alzheimer's disease. Neurosci. Lett. 285: 231-233.

14. Walecki J, Pawłowska-Detko A, Adamczyk M (2007) Rola współczesnych metod obrazowania w rozpoznaniu i monitorowaniu otępienia. Polski Przegląd Neurologiczny, tom $3 \mathrm{nr} 2$.

15. Walecki J (2007) Postępy neuroradiologii: Polska Fundacja Upowszechniania Nauki, Warszawa, 247-249 .

16. Magierski R, Sobów T, Kłoszewska I (2005) Spektroskopia rezonansu magnetycznego w chorobach zwyrodnieniowych ośrodkowego układu nerwowego Postępy Psychiatrii i Neurologii, tom 14, nr 2.

17. Hsu Yuan-Yu, Du An-Tao, Schuff N, Weiner MW (2001) Magnetic resonance imaging and magnetic resonance spectroscopy in dementias. J GeriatrPsychiatrNeurol 14: 145.66.

18. Kantarci K, Jack CR Jr, Xu YC (2000) Regional metabolic patterns in mild cognitive impairment and Alzheimer.s disease: a 1H MRS study. Neurology 55: 210.7.

19. Molina JA. Garcia-Segura JM, Benito-Leon J (2002) Proton magnetic resonance spectroscopy in dementia with Lewy bodies. Eur Neurol 48: 158.63.

20. McKeith IG, Perry EK, Perry RH (1999) Report of the second dementia with Lewy bodies international workshop: diagnosis and treatment. Consortium on dementia with Lewy bodies. Neurology 53: 902.5.

21. Gut M, Marchewka A (2004) Funkcjonalny rezonans magnetyczny - nieinwazyjna metoda obrazowania aktywności ludzkiego mózgu Konferencja " 'Nowe metody w neurobiologii" Konferencja " Nowe metody w neurobiologii" 15.12.2004: 35-40.

22. Rombouts S.A., vanSwieten J.C., Pijnenburg Y.A (2003) Loss of frontal fMRI activation in early frontotemporal dementia compared to early AD. Neurology 60 (12): 1904-1908.

23. Goekoop R., Rombouts S.A., Jonker C (2004) Challenging the cholinergic system in mild cognitive impairment: a pharmacological fMRI study. Neuroimage 23 (4): 1450-1459.
24. Zimny A., Sąsiadek M., Leszek J (2007) Does perfusion CT enable differentiating Alzheimer's disease from vascular dementia and mixed dementia? A preliminary report. J. Neurol. Sci.257 (1-2): 114-120.

25. Streitparth F., Wieners G., Kamena A (2006) Diagnostic value of multislice perfusion CT in dementia patients. Radiologe Nov 29; [pub ahead of print].

26. Motyl R (2007) Otpienie - kryteria diagnostyczne Polski Przegląd Neurologiczny, tom 3.

27. Adamczyk M., Walecki J., Bekiesińska-Figatowska M (2006) Application of fMRI in the evaluation and prediction of progress to Alzheimer's disease in patients with mild cognitive impairment. Pol. J. Radiol. 71 (2): 77-86.

28. Pawłowska A., Walecki J.,Gabrylewicz T i wsp. Zmiany stężeń $\mathrm{N}$-acetyloasparginianu, choliny i mioinozytolu $\mathrm{w}$ obrębie formacji hipokampa w grupie osób z łagodnymi zaburzeniami poznawczymi (MCI) w spektroskopii protonowej rezonansu magnetycznego (1HMRS) doniesienia wstępne. Pol. J. Radiol. 2004; 69 (2): 7-15

29. Jack C.R. Jr, Petersen R. C., Xu Y (1998)Rate of medial temporal lobe atrophy in typical aging and Alzheimer's disease. Neurology 51 (4) : 993-999.

30. Du A.T., Schuff N., Zhu X.P (2003) Atrophy rates of entorhinal cortex in $\mathrm{AD}$ and normal aging. Neurology 60 (3) 481 - 486.

Address for correspondence:

Katedra i Zakład Radiologii i Diagnostyki Obrazowej ul. Skłodowskiej-Curie 9

85-094 Bydgoszcz

tel.: 625854680

fax: 525854050

Received: 7.05.2014

Accepted for publication: 2.09.2014 